\title{
The first loess map and related topics: contributions by twenty significant women loess scholars
}

https://doi.org/10.1515/geo-2018-0024

Received January 8, 2017; accepted June 5, 2018

\begin{abstract}
Women scholars have contributed to the study of loess. Charlotte Hibbert made the first map of loess distribution and there were many subsequent achievements. The twenty people selected represent a subjective choice; there is no overall biobibliographical metric that can be applied. The twenty are mss: Hibbert, Owen, Swineford, Conea, Marković-Marjanović, Fotakieva, Ivanova, Davin, Coude-Gaussen, Wintle, Matviishina, Gerasimenko, Billard, Grabowska-Olszewska, Sycheva, Mavlyanova, Rendell,Łanczont, Klukanova, Morozova. The INQUA Loess Commission provides a convenient temporal divide, and also a divide in style of loess investigation: early studies pre-Commission; Loess Commission activities; modern scientific loess research post-Commission (after 2003).
\end{abstract}

Topics: Hypotheses of loess formation, aeolian vs. fluvial, aeolian vs. in-situ, desert loess, Danubian loess, INQUA Loess Commission, Dating techniques, hydroconsolidation, loessification, Ukraine, Russia, Central Asia, loess structure.

The paper by Jelena Marković-Marjanović in the 1961 INQUA Loess Symposium was one of the key pioneering documents in the development of loess stratigraphy; it should be more widely recognized.

Keywords: loess history, women scholars, INQUA Loess Commission, first loess map, loess formation theories, biobibliography of loess

\footnotetext{
Kathryn Fitzsimmons: Research Group for Terrestrial Palaeoclimates, Max Planck Institute for Chemistry, Hahn-Meitner-Weg 1, 55128 Mainz, Germany, E-mail: k.fitzsimmons@mpic.de

Sue McLaren: Centre for Loess Research \& Documentation, School of Geology, Geography \& the Environment, University of Leicester, Leicester LE1 7RH, UK

^Corresponding Author: Ian Smalley: Centre for Loess Research \& Documentation, School of Geology, Geography \& the Environment, University of Leicester, Leicester LE1 7RH, UK,

E-mail: ijsmalley@gmail.com
}

"Much has been written on loess deposition but those upholding the merits of the two opposing theories have been unable to agree that any evidence yet discovered could be accepted as conclusive.” Luella Owen 1905

In Memory of Jewel Elizabeth Davin 1947-2012

\section{Introduction}

Women have contributed to the study of loess in many ways over many years; this paper is a first assessment of the nature and extent of that contribution. It is divided essentially into three parts: early studies, say up to 1960; then the period of the activity of the INQUA Loess Commission, in particular when headed by Julius Fink, 19602000; and after, post 2000, the modern era, in which there was a sudden burst of loess-related activity, made possible by the opening-up of new regions of loess terrain and scientific developments in analytical and dating techniques. The choices are somewhat arbitrary, particularly in the post-2000 section; but the earlier choices are probably sound, and have been discussed with senior contemporary loess scholars. The 'Women \& Loess' project fits comfortably into the Loess Biobigliographical Project which has been covering loess history since 1975.

The Loess Biobibliographical Project (LBP) was started with the Benchmark Collection of loess papers [1], at the initiative of Rhodes Fairbridge of Columbia University. It has progressed, erratically but continuously, since then. The aim is that the history of loess research should be told via the people who made the advances, and that actual advances can be illustrated by selections and excerpts. The LBP has had one or two high-points; significant loessic events were identified for the first LoessFest meeting at Heidelberg and Bonn in 1999 [2]; an attempt was made to identify 100 significant loess people for the Wroclaw meeting in 2011 [3]; the very beginnings of loess research have been identified and discussed [4]; certain key individuals have been identified and studiede.g. Charles Lyell $[5,6]$ and L.S.Berg [7]; the paradigm 
shifts have been identified and considered [8]; local developments have been listed - e.g. in New Zealand [9], 50 Russian authors have been identified - but so far only poetically [10].

The aim of the present paper is to consider the contribution by women to loess science and scholarship. There is a growing appreciation that the contribution made by women to science has perhaps been undervalued and overlooked. Volumes are appearing to address this shortcoming [11-13], this paper is a contribution to the trend.

\section{Method and results}

The selection is essentially subjective (but trying to be objective), with a weighting towards relatively recent contributors. Obviously as loess science develops and expands there will be more investigators and scholars involved. But we can claim one very significant, and so far unrecognised, early contributor. The first map to show loess distribution was made by a woman, by Charlotte Hibbert around 18281830, in the Eifel region of Germany [14]. She has no publications under her own name but the map was published as an annexe to her husband's book on the Rhine volcanoes [15] (Fig. 1). It is fitting that the publication of the INQUA Loess Map of Europe was supervised by a woman, nearly 180 years later [16].

\subsection{Charlotte Hibbert}

Map maker (Fig. 1); illustrator of loess landscapes (Fig. 2). When Charles Lyell visited Charlotte Hibbert and husband Samuel in September 1831 they talked about volcanoes and loess and the region of the Rhineland that the Hib-

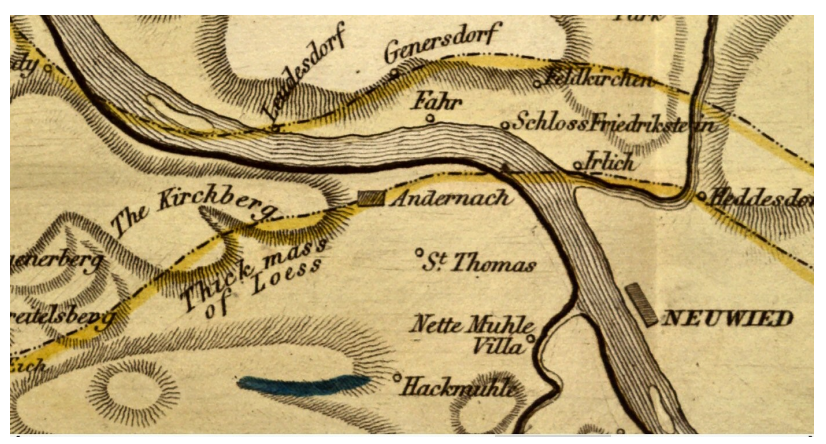

Figure 1: Map (portion of...) by Charlotte Hibbert [14]; attached to the book by S. Hibbert [15], the first representation of loess distribution. (see whole map at Romantic Circles website https: //www.rc.umd.edu/node/38560

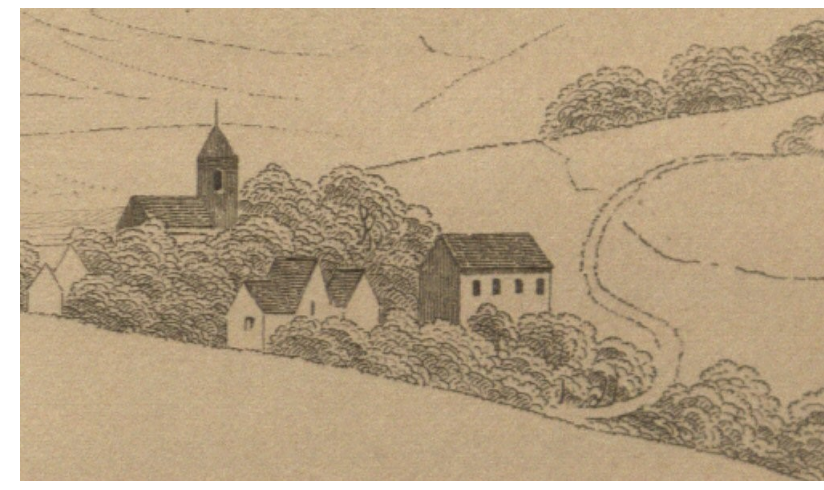

Figure 2: Loess landscape, a sketch by Charlotte Hibbert; the village of Eich, near the Laacher See.

berts had explored and mapped in the previous years. Lyell recorded the conversation about 'the loess from Kruft to Andernach' and remarked on the skill of Charlotte in producing the map and illustrations. A very considerable map was produced (Fig. 1) and it appeared as part of their report [15]. It was Fig. 1 and described as a frontispiece; it was in fact a separate map sheet and was not bound in with the text. It should essentially be considered a separate publication, and given a separate bibliographic existence [14]. By chance the work of the Hibberts was chosen to illustrate aspects of the Romantic Movement (see Romantic Circles website, www.rc.umd.edu). The book [15] is now readily available but it is always supplied without the map. The map has been neglected; Schwarz [17] in his study of the Siebengebirge shows a whole range of historical maps of the region but does not mention the work of the Hibberts. He cites the work of Horner [18] on the geology of the Bonn region and reproduces the Horner map, which was attached to his paper. In fact he gives Horner pioneer status and states 'Er erstellte dir erste Karte des Siebengebirges', we think that some portion of this honour is owed to Charlotte Hibbert.

\subsection{Luella Owen}

The loess of St. Joseph, the Mississippi River bluffs. Luella Owen (Fig. 3) appears to be the only woman loess investigator to feature in the earlier bibliographies; her work was listed by Stuntz \& Free [19], by Scheidig [20] and others [21, 22]. We think that she is also the only one of that group to feature in Wikipedia. Her work is reasonably well known and Creese [23] provided a short biography for the Burek \& Higgs [13] study of early women geologists. She is known in the wider world and there is book length study by Eberle [24]. Creese [23] reported her work as a cave ex- 


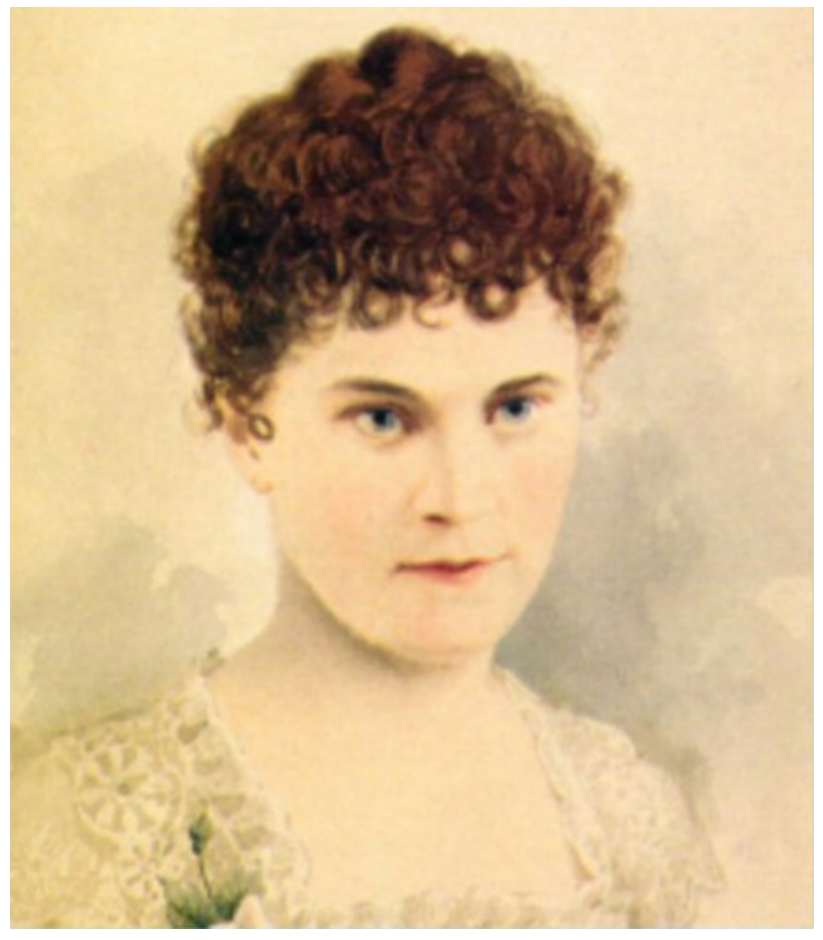

Figure 3: Luella Owen. This is the young Luella, pictured at about 1872.

plorer and stated that 'in about 1900 she returned to the study of loess'. Her papers [25-27] feature in many bibliographies.

\subsection{Ada Swineford}

Particle size analysis; theories of loess deposit formation.

Ada Swineford (Fig. 4) worked at the Kansas Geological Survey, she was very much a Kansas geologist. She worked with John Frye and carried out studies on the nature of loess, particularly dust/loess comparisons [28, 29], (Fig. 5). Underwood et al. [30] produced an elegant memorial for her soon after her death in 1992. Ada Swineford was active in the USA at a time when there was considerable discussion on the mode of formation of loess deposits. Russell [31] had produced a view of loess formation which was remarkably similar to the 'loessification' of L.S. Berg, and there was much response, and many attempts to refute this new 'in-situ' theory and support the default aeolian approach. Russell [31] was a remarkable paper and it had appended an impressive bibliography (including [25-27]). Aspects of loessification still echo and reconciliations are still being attempted [32]. Swineford was involved in the aeolian vs. in-situ controversy, Owen was involved in the aeolian vs. fluvial controversy.

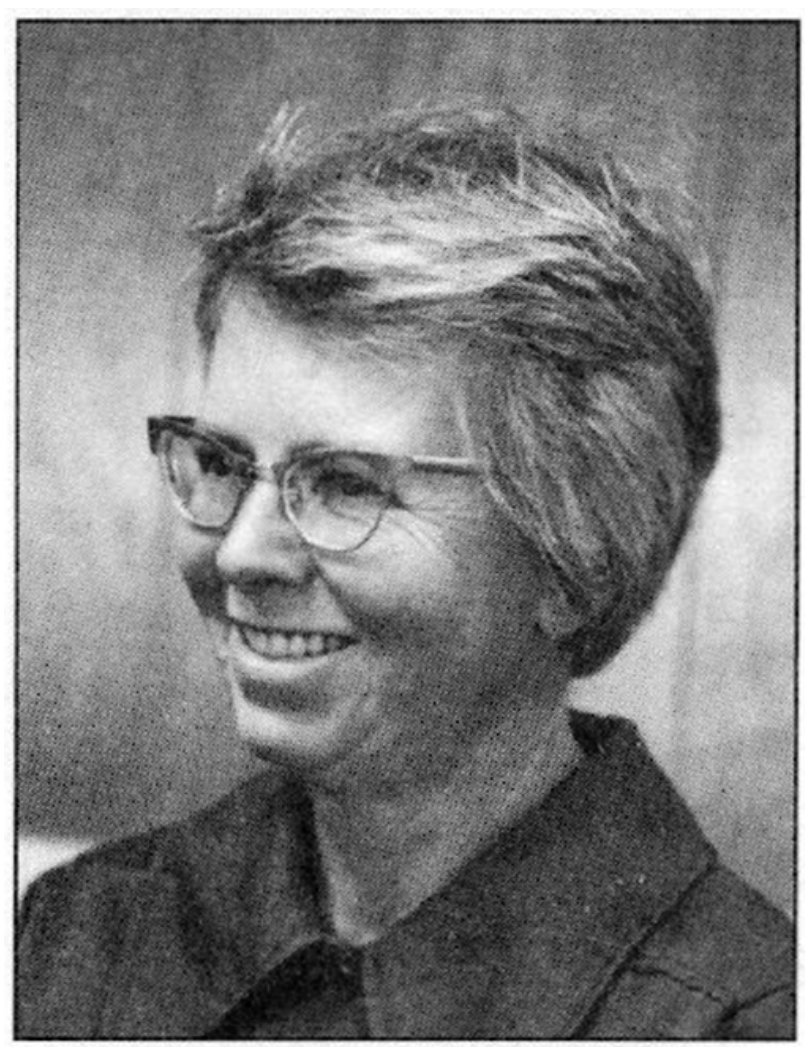

Figure 4: Ada Swineford (1917-1992).

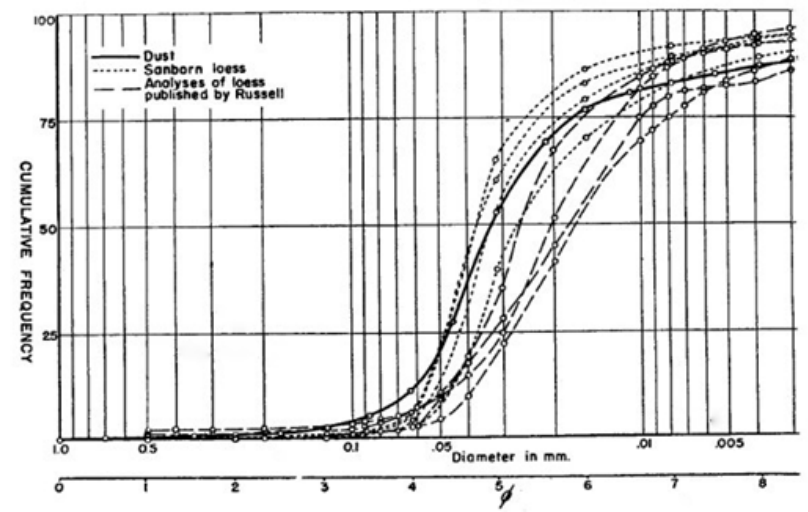

Figure 5: Size distribution of loess material and aeolian dust, from Swineford \& Frye [28]. The similarity of particle size distribution of loess and freshly gathered aeolian material provided evidence relating to the veracity of the Russell [31] 'in-situ' theory of loess formation. 


\subsection{Ana Conea}

Ana Conea was killed in the great Bucherest earthquake of 1978 [33]. She had been a notable Romanian investigator of loess, and helped in the compilation of the field guide for the INQUA Loess Commission meeting in Romania in 1972 [34]. She worked mainly in the Dobrogea region [35, 36].

"Dobrogea, a region situated in the south-eastern part of Romania between the Danube river and the Black Sea, is covered mostly by loess and loesslike deposits, in which several buried soils can be identified.

On the greatest part of its distribution area, the loess presents typical characteristics: unstratification, high porosity rate (52-55\%), parting along vertical faces, colours in 10YR or 2.5Y hues with values of 5-5.5 and chroma of 4, moist, and values of 6-7, with the same chroma, when dry. Its lime content is on the average 15$20 \%$. The clay fraction, of the last loess layer at least, is dominantly an illitic-montmorillonic material.” [36].

\subsection{Jelena Marković-Marjanović}

Loess in former Yugoslavia; member of Loess Commission. It has turned out that the loess in Serbia, in the northern part of the former Yugoslavia, is some of the best developed and most scientifically rewarding of the loess in Europe. The stratigraphy of the Serbian loess has provided many new chronological insights [37].

Jelena was a significant pioneer in the study of the Serbian loess [38-40].

As the study of Danubian loess has developed the inputs from Serbia, Bulgaria, Romania etc. are seen as very important [37, 41, 42]. Of all the parts of the former Yugoslavia Serbia has proved to be the most loess rich and a considerable tradition of loess research has developed there. This is part of an appreciation of the loess in the Danubian region as a whole and a recognition of the Danube as a major loess river.

We propose that the contribution made by Jelena Marjanović-Marković was one of the most significant made by a woman loess scholar. She participated in the Symposium on Loess organised by Julius Fink at the $6^{\text {th }}$ INQUA Congress in Poland. That moment in 1964 was a critical event in the development of loess research. The eleven papers presented at the symposium represent the seminal moment of modern loess research. Marković-Marjanović demonstrated the importance of loess in Yugoslavia and pointed towards a remarkable regional future.
“La Yougoslavie est situee au Sud de l'Europe. Ses parties les plus meridionales ont la latitude geographique de Naples $\left(41^{\circ}\right)$, tandis que les parties les plus septentrionales atteignent $46^{\circ}$ de latitude Nord. Pourtant, maslgre sa sortie a l'Adriatique, les influences de la Mer Egee et sa situation meridionale marquee, la couverture de loess y est fort developpee.

Le loess recouvre de vastes etendues, particulierement au Nord ou il attaint une epaisseur considerable. Il montre le caractere polyphase, en comprenant aussi les sols fossils. Les profiles de loess sont partout de structure semblable et s'etendent sur plusiers dizaines de kilometres. Ils sont developpes dans une serie de localites et indiquent leur caractere regional et non seulement les conditions locales de leur origine.” [38].

The map produced for this 1964 paper (Fig. 6) was one of the first to show clearly the extent and positioning of the loess deposits in Serbia- which have turned out to be among the most significant and valuable of the European loess deposits (Fig. 7).

\subsection{Elena Fotakieva}

s Loess in Bulgaria; member of Loess Commission. Fotakieva and Minkov [43-45] described the loess of northern Bulgaria. Fotakieva was an early member of the Loess Commission and took part in its founding activities. She contributed to the $7^{\text {th }}$ INQUA Congress in the USA, and the $8^{\text {th }}$ in Paris. These were critical meetings for the development of organised loess research and Fink organised a symposium at each gathering where world activities in loess were examined [46, 47].

\subsection{Irina Konstantinovna Ivanova}

Loess in the USSR; member of Loess Commission. She was much involved in the $13^{\text {th }}$ INQUA Congress held in Moscow in 1986 [48]. She was a member of the Loess Commission in the early Finkian days and represented the USSR $[49,50]$.

\subsection{Armelle Billard}

Loess stratigraphy; worked with Edward Derbyshire on the 'Landslides in Lanzhou' project [51]; author of a classic text on Quaternary stratigraphy [52]. Faugeres [53] commented on her contributions:

"La contribution d'A.Billard a ce courant s'appuie sur le constant d'une contradiction entre la theorie classique 


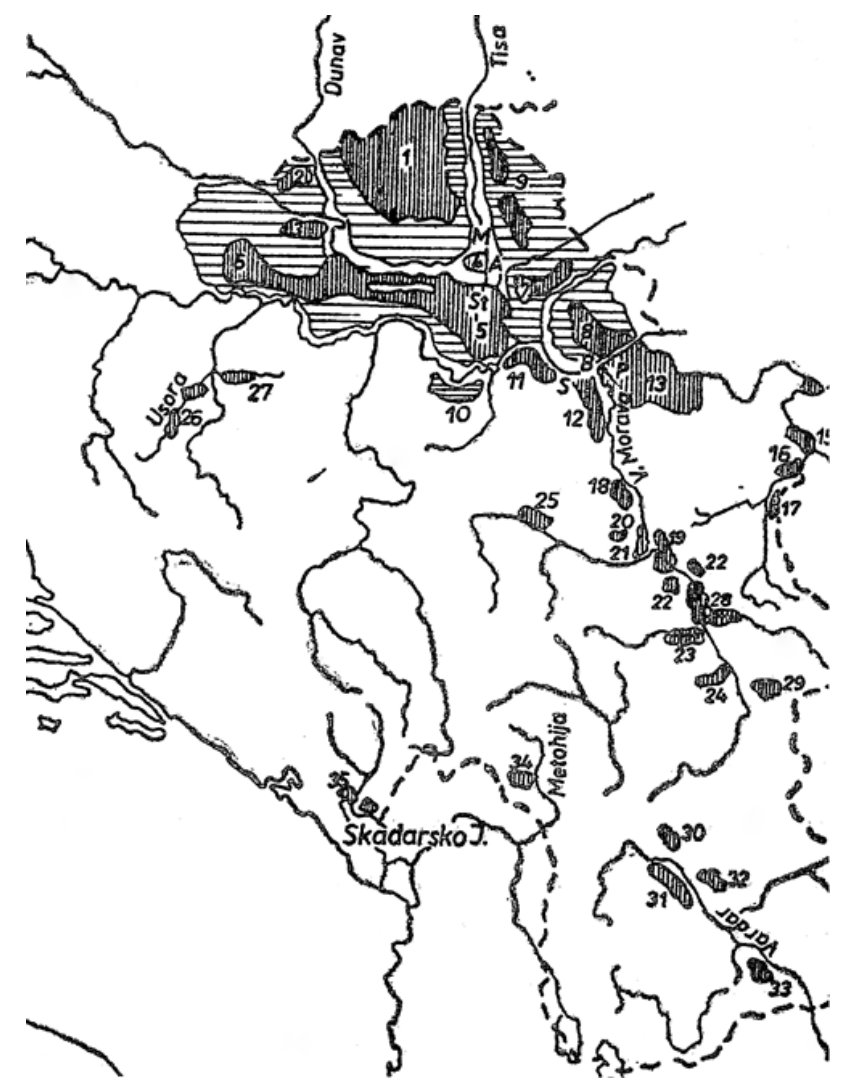

Figure 6: Sketch map of loess distribution in Yugoslavia, from Marković-Marjanović [38]. This is part of Fig. 1 showing the loess in Serbia. Vertical hatching: continental loess, horizontal hatching: swamp loess (loess paludeen). Locations: 1-9 loess plateau of the Pannonian basin; 10-13 loess on the southern edge of the Pannonian basin; 14-27 scatterings of loess in the fluvial valleys; 28-34 loess in the mountain valleys; 35-37 scattering of loess in the Adriatic region. An important early representation of loess in Serbia.

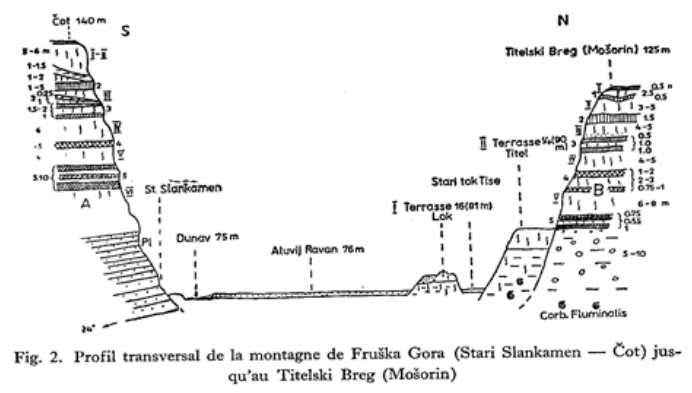

Figure 7: Classic loess sections in Serbia, from MarkovićMarjanović [38]. A transverse profile of the Fruška Gora mountain (with original caption). des 'glaciations alpines' et les donnees stratigraphiques fournies par l'etude des loess et des sediments marins profonds.” [53].

\subsection{B. Grabowska-Olszewka}

Engineering geologist; microstructure of engineering soils; particularly SEM studies of loess soils [54-56]. There is a long running theme of loess investigation in the fields of engineering geology and soil mechanics. The most significant problem is that of hydroconsolidation and subsidence in loess ground. This depends very much on the open structure of loess and it is here that GrabowskaOlszewska made her contributions, and it is here that most loess research in engineering soil science has been concentrated [57].

\subsection{Jewel Davin}

Bibliographer and librarian. Long-time librarian at the DSIR[Department of Scientific and Industrial Research] New Zealand Soil Bureau headquarters at Taita in the Hutt Valley just north of Wellington. It was in this ridiculous place because it was thought that there were going to be field trials on the land around- but, of course, there never were. Jewel was a committed bibliographer, one of New Zealands finest $[9,58,59]$ and she was also involved in some loessic endeavours. She cooperated in the long term efforts to gain recognition for John Hardcastle as a pioneer in loess stratigraphy [60], and also in bibliographic studies on New Zealand loess and fragipan horizons in loess $[9,59]$. Given the resources of DSIR she was able to cooperate in the development of the 'descriptive bibliogaphy' a cross between a bibliography and a monograph, the first of which appeared as Bibliographic Reports of the Soil Bureau.

\subsection{Genevieve Coude-Gaussen}

Desert loess; dust from the Sahara; loess around the Mediterranean [61-65].

Coude-Gaussen considered loess material produced in the Sahara and distributed to neighbouring regions. She made contributions to the long-running but erratic discussions about 'desert loess'. The problems with desert loess were that it was rather elusive and that it was difficult to devise a satisfactory mechanism whereby loess-sized particles could be produced in hot, dry desert environments. 


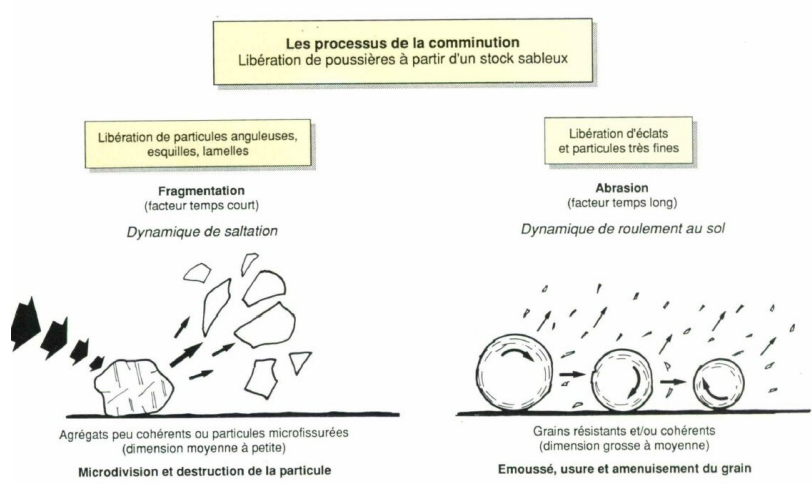

Figure 8: Particle making by particle impact in desert regions, from Coude-Gaussen [63].

Obruchev [66] probably originated the idea of a specific 'hot' loess in 1911, but Penck claimed to be unable to detect loess deposits around the Sahara; it lacked a 'loessgirdle' (fehlt ein loessgurtel). The 'desert loess' discussion was activated by Butler [67] in Australia who claimed after examining large tracts of desert territory that it seemed that desert loess did not exist.

Coude-Gaussen favoured a particle impact mechanism to produce potential loess material (Fig. 8). It does seem feasible that some such mechanism operates in the sandy regions of the Sahara [68] but the product is restricted to the very small sizes, perhaps around $3 \mu \mathrm{m}$; production of large fragments, say around $30 \mu \mathrm{m}$ is not observed. Small dust is produced from Saharan regions in large quantities, from old lake beds and from dune areas, but not large loess dust.

Coude-Gaussen concentrated on small dust but she made significant contributions to the study of airfall deposits associated with the Sahara and the Mediterranean.

\subsection{Ann Wintle}

Pioneer in luminescence dating, key studies on UK loess.

The great advance in loess studies came in the middle of the $20^{\text {th }}$ Century when it was realised that the loess deposits contained an accessible record of climate change. John Hardcastle had realised this back in 1890 but it was only when Liu Tung sheng and collegues in China examined their vast deposits that the potential began to be realised. Luckily this realisation went hand in hand with the development of new ways of dating loess. Accurate dating of loess deposits gave a new window on to Quaternary stratigraphy and chronology, and made research on dating methods popular and relevant. Ann Wintle (Fig. 9) was

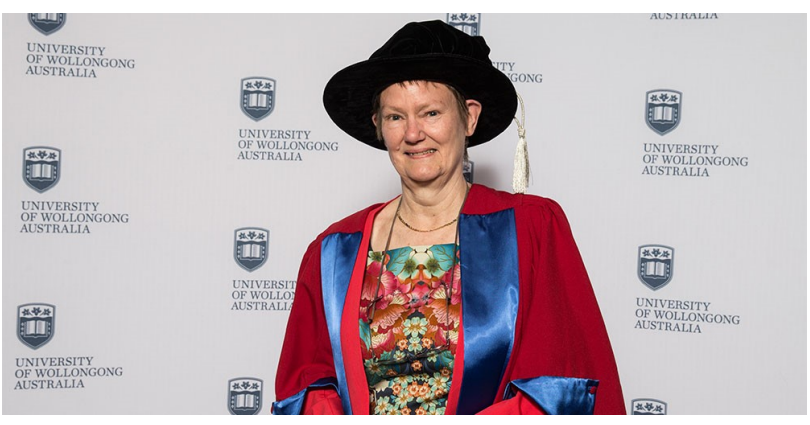

Figure 9: Ann Wintle; pioneer of luminescence dating.

a leading pioneer in luminescence dating, and has been widely recognised as such.

Luminescence dating was well fitted for use with loess deposits. Wintle made some major observations on loess in Britain and produced the first detailed dating of the UK loess deposits [69-75].

\subsection{Tatiana Morozova}

Loess in Russia [76]; she was cited by Kriger [77]. Micromorphology of fossil soils and loess [78-80].

\subsection{Zhanna Matviishina}

Loess in Ukraine; represented Ukraine at the 1999 LoessFest meeting in Heidelberg and Bonn [81, 82]. Matviishina was the long-time head of the palaeogeographical section of the Institute of Geography of the National Academy of Sciences in Ukraine.

\subsection{Natalia Gerasimenko}

Loess in Ukraine; organised the SEQS meeting in Ukraine in 2001 [82]. A specialist in reconstruction of vegetational successions in loess-soil sequences [83, 84].

\subsection{Nadira Mavlyanova}

Loess in Uzbekistan. The great pioneer of the study of loess in Uzbekistan was G.A.Mavlyanov; his daughter Nadira carried on loess studies from her base in Tashkent [85-87]. Her field is engineering geology, she worked with Trofimov in Moscow and Jefferson in Nottingham. 


\subsection{Svetlana Sycheva}

Loess in Siberia; appreciations of the work of R.S.Il'in. Siberia is one of the neglected loess regions of the world, neglected even though V.A.Obruchev, perhaps the most important Russian scholar, spent a significant part of his career at Tomsk. The loess regions of Siberia must be one of the investigated loess regions for the near future. They have suffered neglect because of difficulty of access and lack of local scholars to lead the investigations (the same reasons that loess was neglected in India or New Zealand). Sycheva is a major investigator of Siberian loess.

Sycheva has written on Siberian loess $[88,89]$ but she has also made careful contributions to preserve the memory and sustain the loessic thinking of R.S.Il'in. Il'in was an original thinker on loess and had much to contribute to the loess debate but he was severely persecuted by the Soviet state and eventually killed in the NKVD terror of 1936-1939. Attempts have been made to preserve his memory and to draw attention to his loessic writings; and one of the main Il'in supporters has been Sycheva [90].

\subsection{Maria tanczont}

Loess in Poland and Central Europe. Detailed studies on loess sedimentation in particular in eastern Poland and western Ukraine; and investigations of Gravettian sites [91-95].

"Yezupil village is situated on the left bank of the Bystrycya River, near its confluence with the Dniester River, in the East Carpathian Foreland about $40 \mathrm{~km}$ from the mountains... Loess deposits are widespread in the whole area, except for the bottoms of valleys. Loess is several to several dozen metres thick and forms the most westerly part of the East European loess province” [95].

\subsection{Alena Klukanova}

Loess in Slovakia; problems with hydroconsolidation.

The problem of hydroconsolidation was, and is, the most important geotechnical problem involving loess ground [57]. It has largely been tackled by investigators in Central and Eastern Europe; and Klukanova has been involved in these endeavours [96].

\subsection{Helen Rendell}

Desert loess, Luminescence dating, Loess in Pakistan [97, 98]. The work on loess in Pakistan is noteable; there has not been much investigation of loess on the Indian subcontinent and every contribution is appreciated. Given the large cold mountains to the north, the presence of large rivers, even sandy deserts for the storage of loess material it is necessary that there be loess deposits inn India and Pakistan. There are recent indirect references to the loess in the north [99] but there is room for a vast increase in loess research on the sub-continent.

\section{Discussion}

Organised loess investigation began in 1961 with the founding of the Sub-commission for Loess of the Stratigraphy Commission of INQUA- the International Union for Quaternary Research. The Loess Sub-commission was founded by Julius Fink of the University of Vienna at the $6^{\text {th }}$ INQUA Congress in Poland. It became a full INQUA Commission at the $8^{\text {th }}$ INQUA Congress in Paris in 1969. From the beginning, largely because the activity was focussed in Central and Eastern Europe, there was a proper contribution by women loess scientists. (e.g. Conea, Ivanova, Marković-Marjanović, Fotakieva, Morozova). The early years of the Loess Commission have been described by Smalley et al. [100]; it was for many years a Central European enterprise but then suddenly in 1978 it branched out into the Pacific region [101].

There are two significant marker volumes from the early days of the Loess Commission that allow the scope of its activity to be studied and assessed: these are the report from the $7^{\text {th }}$ USA Congress [46], and the report for the $8^{\text {th }}$ Paris Congress [47]. There are significant contributions from various women scientists.

The report for the Paris INQUA Congress presents bibliographic problems: the first is that there is no editor or compiler identified, which makes a Harvard style reference difficult. We propose to refer to this document as AFEQ 1969 [47], it was presented as a supplement to the Bulletin de l'Association Francaise pour l'Etude du Quaternaire. Women contributors were Fotakieva, Conea, Ivanova and Marković-Marjanović. There is a problem with the observations in Spain and Greece, which are certainly by Brunnacker but are listed in the 'table des matieres' as by G.Jankovic of Osijek. This was a defining moment for the Loess Commission; in AFEQ 1969 Fink set out his vision for a co-ordinated study of loess across Europe; boundaries would be crossed and a great continent wide study of loess stratigraphy would be achieved.

Bibliographies; as it happens the part of Quaternary studies which is best supplied with bibliographies is the 
study of loess. Loess scholars have always been aware of the vast amount of material published relative to their subject; Paul Woldstedt claimed that 'Die Literatur uber den Loess ist ungeheuer' there are various ways of translating ungeheuer but many people choose monstrous. So bibliographies are required and these provide a basis for the search for women scholars and authors.

A study of loess bibliographies could start with the assemblage made by S.C.Stuntz to accompany the report on wind-blown soils compiled by E.E.Free [102]. This has always provided something of a bibliographic hurdle; the best way to access this remarkable bibliography is to consult the 1991 republication [19]. This is a truly remarkable piece of bibliographical enterprise; Stuntz managed to cover the literature available in 1911 with amazing thoroughness, and he gives forenames to the authors which enables women contributors to be identified. He also manages to cope with the Cyrillic alphabet so there is interesting early Russian coverage; it is a fantastic document, much admired by bibliographers. Unfortunately it reveals very few women. There is a mention of a Lady Anna Isabella Noel King Noel writing about 'A pilgrimage to Nejd' but only one bona-fide loess entry: Luella Owen. Lady Anna might more properly be known as Anne Isabella (King-Noel) Blunt.

Scheidig [20] was for many years the only authoritative study of loess; it carries with it a substantial bibliography and a thorough examination reveals Owen [25-27], but no other women authors.

\section{Conclusions}

Twenty significant women loess scholars and investigators can be identified and discussed. There are more, this is not an exclusive list, but these are twenty significant individuals who have contributed to science in a whole variety of ways. A temporal cut-off might be placed at about 1990; the twenty are in place before 1990, but this might be an absurd distinction. Perhaps a tri-partite division into early works; those associated with the INQUA Loess Commission; those writing in relatively modern times- the postFink world; would be more suitable.

As always in the writing of loess history we run up against the problem of the under representation of scholars who wrote in Russian. It is not just the difficulty of obtaining literature in Russian but the reticence of Russian scholars to write about early developments in their subject, which causes problems. Kriger [77] produced a substantial study (for the $7^{\text {th }}$ INQUA Congress in the USA) which has underpinned most of our considerations, although more recent material has been supplied by Trofimov [103]. Kriger lists over 400 publications in Russian (or Ukrainian) from 340 authors. Of this 340 authors perhaps ten are women, about $5 \%$ of the material is produced by women authors but none of them appear to make a particularly significant contribution. Smalley [104] analysed the author contributions in the Kriger bibliography and found the first woman appearing at no. 50 on the list of most prolific authors; this was T.D.Morozova who contributed four publications, she has two entries on the Trofimov [103] list. Trofimov gives some prominence to Bolikhovskaya (eight entries) and she should perhaps feature on the default 20 list. Trofimov lists 318 Cyrillic references.

Herodotus said that it was the duty of historians to recognise critical points in the progress of history and to indicate when fundamental change occurred. For women in loess, and in fact for loess studies in general, a critical point was the $8^{\text {th }}$ INQUA Congress in Paris in 1969. Here Julius Fink laid out a plan for loess research [47], and a significant number of women participated in the Loess Commission which he invented. It is perhaps fitting that the symbol for the $8^{\text {th }}$ Congress was the image of a female deity (La dame de Brassempouy), representing all of Quaternary endeavour (Fig. 10).

\subsection{Afterword}

A special issue of Quaternary International was produced to celebrate the life and achievements of Marton Pecsi, of the Hungarian Academy of Sciences [105]. This issue (\#152/153) dealt largely with loess, it contained 20 papers, and there were authorial contributions from the following women scholars: Maria Łanczont, Bozena Lacka, Teresa Madeyska, T.D.Morozova, Guzel Danukalova. Nataliya Bolikhovskaya, T.A.Sadchikova, A.N.Simakova, N.G.Mavlyanova, Tatyana Gendler, G.A.Pospelova, Krystyna Kenig, S.N.Timereva, A.N.Drenova, Elena Novenko and S.Y.Sycheva.

A total of 16 contributions - suggesting that women now play a significant part in loess studies.

Acknowledgement: We acknowledge the contributions made by members of the INQUA Loess Focus Group to the discussions on important women loess investigators; we also thank surviving members of the original INQUA Loess Commission for their input. We acknowledge the subjective nature of the choices for the default 20; we hope that the list can be expanded and improved. Women scholars writing in Russian are probably under-represented; we of- 


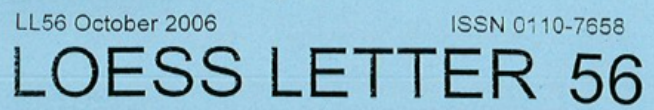

An INQUA Newsietter for Students of Loess Material, Loess Deposits, Loess Ground, Loess Soils \& Loess as a 'Climate Register'. Founded in 1979 at the New Zealand Soil Bureau.

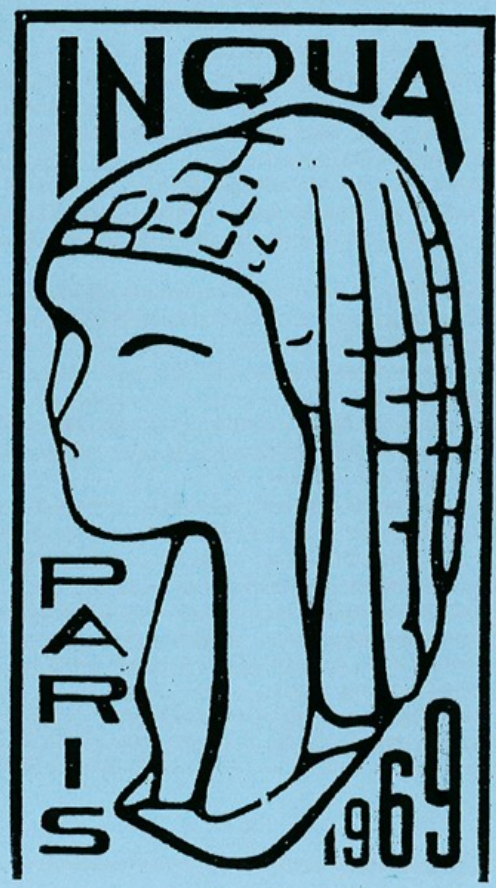

Figure 10: The logo for the 1969 Paris INQUA Congress; this is the statuette of 'La dame de Brassempouy', reproduced on the cover of Loess Letter 58.

fer continuing tribute to the work of N.I.Kriger without whom studies of the development of loess research in Russia would be very difficult. He deserves more recognition, both in Russia and the World at large. We also thank two reviewers who contributed vast efforts to the improvement and development of this paper; many thanks and appreciations.

\section{References}

[1] Smalley, I.J.(ed.), Loess: Lithology and Genesis. Dowden, Hutchinson \& Ross Stroudsburg, 430p, 1975

[2] Smalley, I.J., Jefferson, I.F., Dijkstra, T.A., Derbyshire, E., Some major events in the development of the scientific study of loess. Earth Science Reviews, 2001, 54, 5-18

[3] Smalley, I.J., Smalley, G.J., O'Hara-Dhand, K., Jary, Z., The Loess Biobibliographical Project, with some emphasis on Polish investigators. Quaternary International, 2013, 296, 7-14

[4] Jovanović, M., Gaudenyi, T., O’Hara-Dhand, K., Smalley, I.J., Karl Caesar von Leonhard (1779-1862) and the beginnings of loess research in the Rhine valley. Quaternary International, 2013, 334/5, 4-9

[5] Smalley, I.J., Gaudenyi, T., Jovanovic, M., Charles Lyell and the loess deposits of the Rhine valley. Quaternary International, 2015, 372, 45-50

[6] Smalley, I.J., Kels, H., Gaudenyi, T., Jovanović, M., Loess encounters of three kinds: Charles Lyell talks about, reads about, and looks at loess. Geologos, 2016, 22, 71-77

[7] Smalley, I.J., Marković, S.B., O’Hara-Dhand, K., Wynn, P., A man from Bendery: L.S.Berg as a geographer and loess scholar. Geologos, 2010, 16, 109-117 (see also Loess Letter 64 www.loessletter.msu.com)

[8] Smalley, I.J., Marković, S.B., Four loess pioneers: Charles Lyell, F.von Richthofen, V.A. Obruchev, L.S. Berg. Quaternary International, 2018, 469A, 4-10

[9] Smalley, I.J., Davin, J.E., The first hundred years- A historical bibliography of New Zealand loess. New Zealand, Soil Bureau Bibliographic Report 28, 166p, 1980

[10] Smalley, I.J., The names of 50 people who studied loess. All Poetry upload, 2017

[11] Kolbl-Ebert, M., Turner, S., Towards a history of women in the geosciences. In Mayer, W., Clary, R.M., Azuela, L.F., Mota, T.S., Wolkowicz, S., 2017, History of Geoscience: Celebrating 50 years of INHIGEO. Geological Society London, Special Publications, 2017, 442, 205-216

[12] Ogilvie, M.B., Harvey, J.D., Rossiter, M., The Biographical Dictionary of Women in Science. Routledge, London, 352p, 2000

[13] Burek, C.V., Higgs, B., The role of women in the history of geology. Geological Society of London, Special Publication, 281, 2007

[14] Hibbert, C., The volcanic district bounded by the rivers Nette and Bruhl on the Lower Rhine. Map, accompanying Hibbert,S. 15, republished Romantic Circles, 1832 https://www.rc.umd. edu/node/38560

[15] Hibbert, S., History of the extinct volcanos of the Basin of Neuwied on the Lower Rhine. W \& D Laing, Edinburgh, 1832

[16] Haase, D., Fink, J., Haase, G., Ruske, R., Pecsi, M., Richter, H., Altermann, M., Jaeger, K.D., Loess in Europe- its spatial distribution based on a European loess map: scale 1:2,500,000. Quaternary Science Reviews, 2007, 26, 1301-1312

[17] Schwarz, C., Die Geschichte der geologischen Erforschung des Siebengebirges. $2^{\text {nd }}$ ed. Great Space Bonn, 190p, 2014

[18] Horner, L., On the geology of the environs of Bonn. Transactions of the Geological Society of London, 1836, 4, 433-481

[19] Smalley, I.J., The first great loess bibliography: Stuntz \& Free republished-1911-1991. Leicester University, Geography Department, Occasional Paper 19, 1991

[20] Scheidig, A., Der Loess und seine geotechnischen Eigenschaften. Theodor Steinkopff, Dresden U. Leipzig, 233p, 1934

[21] Harding, D.E., Smalley, I.J., Warnock Revisited: A bibliography of North American loess 1805-1955. Leicester University, Geography Department, Occasional Paper, 17, 66p, 1988

[22] Davidson, D.T., Chu, T.Y., Sheeler, J.B., A bibliography of the loess. Engineering Report 8, lowa Engineering Experiment Station, 15p, 1951

[23] Creese, M.R.S., Fossil hunters, a cave explorer and a rock analyst: notes on some early women contributors to geology. In C.V.Burek, B.Higgs eds. The role of women in the history of geology. Geological Society of London, Special Publication, 281, 2007 
[24] Eberle, J.F., The incredible Owen girls. Boars Head Press, St. Louis Mo, 1977

[25] Owen, L.A., The Loess at St.Joseph. American Geologist, 1904, 33, 223-228

[26] Owen, L.A., Evidence on the deposition of Loess. American Geologist, 1905, 35, 291-300

[27] Owen, L.A., Later studies on the Loess. Pan-American Geologist, 1926, 45, 377-382

[28] Swineford, A., Frye, J.C., A mechanical analysis of wind-blown dust compared with analyses of loess. American Journal of Science, 1945, 243, 249-255, (reprinted in Smalley 1, 111-117)

[29] Swineford, A., Frye, J.C., Petrographic comparison of some loess samples from Western Europe with Kansas samples. Journal of Sedimentary Petrology, 1955, 25, 3-23, (reprinted in Smalley 1, 183-190)

[30] Underwood, J.R., Twiss, P.C., Muilenberg, G.E., Franks, P.C., Memorial to Ada Swineford 1917-1992. Geological Society of America Memorials, 1995, 26, 31-35

[31] Russell, R.J., Lower Mississippi loess. Geological Society of America Bulletin, 1944, 55, 1-40, (reprinted in Smalley 1, 7699; bibliography, 93-99)

[32] Smalley, I.J., Jefferson, I.F., O'Hara-Dhand, K., Evans, R.D., An approach to the problem of loess deposit formation: Some comments on the 'in-situ' or soil-alluvial' hypothesis. Quaternary International, 2006, 152/153, 120-128

[33] Smalley, I.J., Ana Conea: obituary. Nature, 1978, 272, 477-478

[34] Conea, A., Bally, R., Canarche, A., Guidebook to the excursion of the INQUA Loess Commission in Romania 11-15 September 1972. Geological Institute Bucharest 42p, 1972

[35] Conea, A., Some features of loess-soil parent material in Central and South Dobrogea. Stiinta Solului, 1968, 6, 177-184, (reprinted in Smalley 1, 285-292)

[36] Conea, A., Quaternary deposits in Dobrogea (Loess and paleosols). Editura Academiei Republicii Socialiste Romania, Bucharest 234p, 1970, (in Romanian)

[37] Marković, S.B., Hambach, U, Jovanović, M., Stevens, T., O'Hara-Dhand, K., Basarin, B., Smalley. I.J., Buggle, B., Zech, M., Svirčev, Z., Milojković, N., Zöller, L. Loess in Vojvodina region (Northern Serbia): the missing link between European and Asian Pleistocene environments. Netherlands Journal of Geosciences, 2012, 91, 173-188

[38] Marković-Marjanović, J., Le loess in Yougoslavie. Report of the $6^{\text {th }}$ INQUA Congress 4, 551-570, 1964

[39] Marković-Marjanović, J., Les profiles de loess du Bassin Pannonique: Region classique du loess de Yougoslavie. In La stratigraphie des loess d'Europe (Bulletin Association Francaise Etude Quaternaire Supplement, AFEQ 1969), 165-172, 1969, (reprinted in Loess Letter 56 see www.loessletter.msu.edu)

[40] Marković-Marjanović, J., Data concerning the stratigraphy and the fauna of the Lower and Middle Pleistocene of Yugoslavia. Palaeogeography, Palaeoclimatology, Palaeoecology, 1970, 8, 153-163

[41] Fitzsimmons, K.E., Marković, S.B., Hambach, U., Pleistocene environmental dynamics recorded in the loess of middle and lower Danube basin. Quaternary Science Reviews, 2012, 41, 104-118

[42] Marković, S.B., Fitzsimmons, K.E., Sprafke, T., Gavrilović, D., Smalley, I.J., Jović, V., Svirčev, Z., Gavrilov, M.B., Bešlin, M., The history of Danube loess research. Quaternary Interna- tional, 2016, 399, 76-89

[43] Fotakieva, E., Minkov, M., Der Loess in Bulgarien. Eiszeitalter und Gegenwart, 1966, 17, 87-96

[44] Fotakieva, E., Minkov, M., The loess in Bulgaria. In Schultz \& Frye, 1968, 46, 297-301

[45] Fotakieva, E., Minkov, M., Le loess en Bulgarie du Nord. In La Stratgraphie des loess d'Europe, 1969, 47, 59-64

[46] Schultz, C.B., Frye, J.C., Loess and Related Eoliasn Deposits of the World. Proceedings of the $7^{\text {th }}$ INQUA Congress BoulderDenver Colorado 1965. University of Nebraska Press, 369p, 1968

[47] AFEQ, La Stratigraphie des Loess d'Europe. Supplement au Bulletin de l'Asssociation Francaise pour l'Etude du Quaternaire, 176p, 1969, (some key material reprinted in Loess Letter 58, see www.loessletter.msu.edu)

[48] Alekseev, M.I., Ivanova, I.K., Neustadt, M.I., $11^{\text {th }}$ INQUA Congress: Summary and Perspectives. Nauka, Moscow, 205p, 1985, (in Russian)

[49] Ivanova, I.K., Les loess de la partie Sud-Ouest du territoire Europeen de l'URSS et leur stratigraphie. In AFEQ 1969, 1969, 47, 151-159

[50] Ivanova,I.K., Kes' A.S., Loess in Yugoslavia. Izv. Akad. Nauk. SSSR, Geographical Series, 1968, 4, 70-78, (in Russian)

[51] Derbyshire, E., Meng, X., Dijkstra, T.A., eds., Landslides in the thick loess terrain of North West China. Wiley Chichester, 246p, 2000

[52] Billard, A., Analyse critique des stratotypes quaternaires. Editions CNRS Paris, 141p, 1987

[53] Faugeres, L., A.Billard: Analyse critique des stratotypes quaternaires. Annales de Geographie, 1990, 99, 209-211

[54] Grabowska-Olszewska, B., SEM analysis of microstructures of loess deposits. Bulletin of the International Association of Engineering Geology, 1975, 11, 45-48

[55] Grabowska-Olszewska, B., Engineering geology problems of loess in Poland. Engineering Geology, 1988, 25, 177-199

[56] Smalley, I.J., Grabowska-Olszewska, B., Loess stratigraphy and Quaternary chronology: examples from China, Poland, New Zealand and England. In Quaternary Chronologies, eds. W.C.Mahaney, GeoBooks Norwich, 57-68, 1984

[57] Rogers, C.D.F., Dijkstra, T.A., Smalley, I.J., Hydroconsolidation and subsidence of loess: Studies from China, Russia, North America and Europe. Engineering Geology, 1994, 37, 83-113

[58] Davin, J.E., Publications by Soil Bureau staff 1975-1979. New Zealand Soil Bureau Bibliographic Report, 28, 1980

[59] Smalley, I.J., Davin, J.E., Fragipan horizons in soils: a bibliographic study and review of some of the hard layers in loess and other materials. New Zealand Soil Bureau Bibliographic Report, 30, 122p, 1982

[60] Smalley, I.J., John Hardcastle on glacier motion and glacial loess. Journal of Glaciology, 1983, 29, 480-484

[61] Coude-Gaussen, G., The perisaharan loess: sedimentological characterization and paleoclimatical significance. GeoJournal, 1987, 15, 177-183

[62] Coude-Gaussen, G., The loess and loess-like deposits along the sides of the western Mediterranean Sea: genetic and paleoclimatic significance. Quaternary International, 1990, 5, 1-8

[63] Coude-Gaussen, G., Les regions-sources de poussieres au Sahara. Science et changement planetaires/ Secheresse, 1990b, 1, 134-141

[64] Coude-Gaussen, G., Les Poussieres Sahariennes. John Libby 
Eurotext, 466p, 1991

[65] Coude-Gaussen, G., Rognon, P., Les poussieres sahariennes. La Recherche, 1983, 147, 1050-1061

[66] Obruchev, V.A., The question of the origin of loess; in defence of the aeolian hypothesis. Izv. Tomsk. Tekhnol. Inst., 33, 1911, (in Russian)

[67] Butler, B.E., Parna- an aeolian clay. Australian Journal of Science, 1956, 18, 145-151

[68] Stuut, J-B., Smalley, I.J., O'Hara-Dhand, K., Aeolian dust in Europe: African sources and European deposits. Quaternary International, 2009, 198, 234-245

[69] Wintle, A.G., Thermoluminescence dating of Late Devensian loesses in southern England. Nature, 1981, 289, 479-480

[70] Wintle, A.G., Stability of TL signals in fine grains from loess. Nuclear Tracks \& Radiation Measurements, 1985, 10, 725-730

[71] Wintle A.G., The dating of loess at Roncourt, Belgium. Geologie en Mijnbouw, 1987, 66, 35-42

[72] Wintle, A.G., A review of current research on TL dating of loess. Quaternary Science Reviews, 1990, 9, 385-397

[73] Wintle, A.G., Luminescence dating: where it has been and where it is going. Boreas, 2008, 37, 471-482

[74] Wintle, A.G., Catt, J.A., Thermoluminescence of soils developed in Late Devensian loess at Pegwell Bay, Kent. European Journal of Soil Science, 1985, 36, 293-298

[75] Wintle, A.G., Shackleton, N.J., Lautridou, J-P., Thermoluminescence dating of periods of loess deposition and soil formation in Normandy. Nature, 1984, 310, 491-493

[76] Morozova, T.D., Evolution of soil formation processes on the Russian Plain during the Quaternary. Pochvovedenie, 3-10, 1972, (in Russian; English translation in Soviet Soil Science, 385-390, 1972)

[77] Kriger, N.I., Loess, its characteristics and relation to the geographical environment. Izd. Nauka, Moscow, 294p, 1965, (in Russian; bibliography republished as Loess Letter Supplement 13, July 1986, for $12^{\text {th }}$ INQUA Congress, Canada, 1987).

[78] Morozova, T.D., Development of soil cover in Europe during the late Pleistocene. Izd. Nauka, Moscow, 281p, 1981, (in Russian)

[79] Morozova, T.D., Identification of palaeosol types and their applicability for palaeoclimate reconstructions. GeoJournal, 1995, 36, 199-205

[80] Morozova, T.D., Nechaev, V.P., The Valdai periglacial zone as an area of cryogenic soil formation. Quaternary International, 1997, 41/42, 53-58

[81] Matviishina, Z., Micromorphology of the Pleistocene soils of Ukraine. Naukova Dumka, Kiev, 152p, 1982, (in Russian)

[82] Rousseau, D.D., Gerasimenko, N., Matviishina, Z., Kukla, G.J., Late Pleistocene environments in the Central Ukraine. Quaternary Research, 2001, 56, 349-356

[83] Gerasimenko, N., Upper Pleistocene loess-palaeosol and vegetational successions in the Middle Dnieper area, Ukraine. Quaternary International, 2006, 149, 55-66

[84] Gerasimenko, N., Rousseau, D-D., Stratigraphy and palaeoenvironments of the last Pleniglacial in the Kyiv Loess region (Ukraine). Quaternaire, 2008, 19, 293-307

[85] Jefferson, I.F., Evstatiev, D., Karastenev, D., Mavlyanova, N.G., Smalley, I.J., The engineering geology of loess and loess-like deposits: a commentary on the Russian literature. Engineering Geology, 2003, 68, 33-351

[86] Jefferson, I.F., Mavlyanova, N.G., O'Hara-Dhand, K., Smalley, I.J., The engineering geology of loess ground: 15 tasks for investigators- the Mavlyanov programme of loess research. Engineering Geology, 2004, 74, 33-37

[87] Smalley, I.J., Mavlyanova, N.G., Rahkmatullaev, Kh.L., Shermatov, M.Sh., Machalett, B., O'Hara-Dhand, K., Jefferson, I.F., The formation of loess deposits in the Tashkent region and parts of Central Asia; and problems with irrigation, hydrocollapse and soil erosion. Quaternary International, 2006, 152/153, 59-69

[88] Sycheva, S.A., New data on the composition and evolution of the Mezin loess-palaeosol complex in the Russian plain. Eurasian Soil Science, 1998, 31, 1062-1074

[89] Sycheva, S.A., Khokhlova, O., Genesis, C-14 age, and duration of development of the Bryansk paleosol on the Central Russian Upland based on dating of different materials. Quaternary International, 2016, 399, 111-121

[90] Sycheva, S.A., Rostislav Sergeevich Il'in- A soil scientist and geologist ahead of his time. European Soil Science, 2007, 40, 341-346

[91] Bogucki, A., tanczont, M., Racinowski, R., Conditions and course of sedimentation of the Middle and Upper Pleistocene loesses in the Halic profile, N.W.Ukraine. Studia Quaternaria, 2000, 17, 3-17

[92] Wilczynski, J., Wojtal, P., tanczont, M., Mroczek, P., Sobieraj, D., Fedorowicz, S., Loess, flints and bones: Multidisciplinary research at Jaksice II Gravettian site (southern Poland). Quaternary International, 2015, 359, 114-130

[93] tanczont, M., Bogutsky, A.B., High-resolution terrestrial archive of climatic oscillations during Oxygen isotope stages 5-2 in the loess-palaeosol sequence at Kolodiiv (East Carpathian Foreland, Ukraine). Geological Quarterly, 2007, 51, 105-126

[94] tanczont, M., Madeyska, T., Environment of the East Carpathian foreland during periods of Palaeolithic man's activity. Catena, 2005, 59, 319-340

[95] tanczont, M., Fedorowicz, S., Kusiak, J., Boguckij, A., Sytnyk, 0., TL age of loess deposits in the Yezupil I Palaeolithic site on the Upper Dniester River (Ukraine). Geologija, 2009, 51, 86-96

[96] Sajgalik, J., Klukanova, A., Formation of loess fabric. Quaternary International, 1994, 24, 41-46

[97] Rendell, H.M., Townsend, P.D., The dating of a $10 \mathrm{~m}$ loess profile in Pakistan. Quaternary Science Reviews, 1988, 7, 251-255

[98] Owen, L.A., White, B.J., Derbyshire, E., Rendell, H., Loessic silt deposits in the western Himalayas: their sedimentology, genesis and age. Catena, 1992, 19, 493-509

[99] Smalley, I.J., McLaren, S., O'Hara-Dhand, K., Bentley, S.P., Loess and bee-eaters III: Birds and ground in the Punjub and the Indus region. Quaternary International, 2016, 399, 234239

[100] Smalley, I.J., Marković, S.B., O'Hara-Dhand, K., The INQUA Loess Commission as a Central European enterprise. Central European Journal of Geosciences Open Geosciences, 2010, 2, 3-8

[101] Smalley, I.J., O'Hara-Dhand,K., The Western Pacific Working Group of the INQUA Loess Commission: Expansion from Central Europe. Central European Journal of Geosciences [Open Geosciences], 2010, 2, 9-14

[102] Free, E.E., The movement of soil material by the wind, with a bibliography of eolian geology. United States Department of Agriculture Bureau of Soils Bulletin, 68, 263p, 1911, (bibliography by S.C.Stuntz, see Smalley 19)

[103] Trofimov, V.T., (eds.), Loess mantle of the Earth and its proper- 
ties. Moscow University Press, 464p, 2001, (in Russian)

[104] Smalley, I.J., Loess- A Partial Bibliography. Geo-Abstracts Bibliography, 7, Geo-Abstracts/Elsevier Norwich 103p, 1980
[105] Velichko, A.A., Dodonov, A.E., Catto, N., (eds.), Loess and palaeoenvironments across Eurasia- Dedicated to the memory of Marton Pecsi. Quaternary International, 2006, 152/153, 1212 